Fountain Journal of Natural and Applied Sciences: 2016; 5(1): 38 - 52
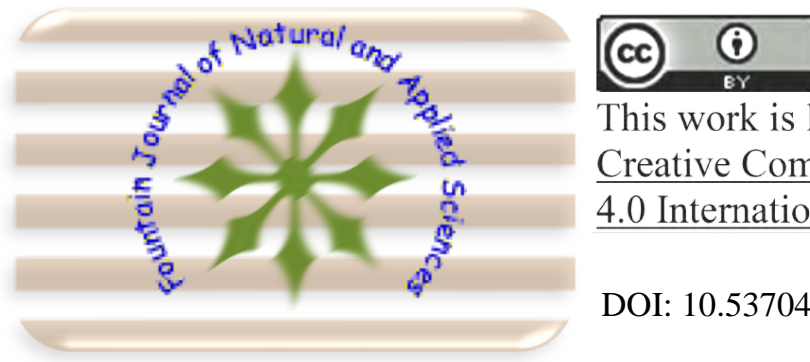

This work is licensed under Creative Commons Attribution 4.0 International License.

DOI: 10.53704/fujnas.v5i1.89

A publication of College of Natural and Applied Sciences, Fountain University, Osogbo, Nigeria. Journal homepage: www. fountainjournals.com

ISSN: 2354-337X (Online), 2350-1863 (Print)

\title{
Comparative Studies of Water and Sediment Qualities of Some Dams in Kwara State
}

\author{
*Abdus-Salam, N., Awoyemi, B. O. and Abdul Raheem, A.M.O.
}

Department of Chemistry, University of Ilorin, Nigeria

\begin{abstract}
Potable water is becoming progressively scarce due to anthropogenic pollution and it has necessitated monitoring of water quality of rivers and dams as a subject of ongoing concern and research. This study was conducted to assess the quality of water collected from four different dams (Agba, Igbaja, Oloru and OmuAran) in Kwara State, Nigeria using standard procedures. Water and sediment samples were collected from three different spatial locations on the dams. The average values of most physicochemical parameters like $\mathrm{pH}$, temperature, Dissolved Oxygen (DO), Biochemical Oxygen Demand (BOD), Total Dissolved Solid (TDS), Total Hardness (TH), Alkalinity, some nutrients such as chloride $\left(\mathrm{Cl}^{-}\right)$, sulphate $\left(\mathrm{SO}_{4}{ }^{2-}\right)$, phosphate $\left(\mathrm{PO}_{4}{ }^{3-}\right)$, nitrate $\left(\mathrm{NO}_{3}{ }^{-}\right)$and some heavy metals such as $\mathrm{Cu}, \mathrm{Zn}$ have values that were within World Health Organisation (WHO) guidelines for drinking water for each of the dams while $\mathrm{Cd}$ and Fe concentrations were observed to be much higher than WHO guidelines for drinking water. This could be as a result of anthropogenic input. The dams' sediments analyzed for heavy metals showed that $\mathrm{Mn}, \mathrm{Zn}$ and $\mathrm{Cd}$ were high in the dams, which can be easily washed into the water body through leaching, thereby causing detrimental effect to the consumers.
\end{abstract}

Keywords: geo-accumulation index, bioavailabilty, nutrient, dam, alkalinity.

\section{Introduction}

Water is one of the world most valuable natural resources and is essential for the maintenance of all forms of life (FAO, 1997). In recent years, because of rapid urbanization, industrialization and growing population, the rate of discharge of pollutants into the environment which ultimately find their way into surface and ground water bodies far exceed the rate of natural purification (Rizwan etal., 2009). Natural water is never absolutely pure, as it carries traces of other substances which bestow on it physical, chemical and bacteriological characteristics. The nature and amount of these substances called impurities vary

\footnotetext{
*Corresponding author: +2348033950752
}

Email address: nasalami2002@yahoo.co.uk 
with sources of the water. Although, most of the water on earth is not accessible, the surface water, which is the most accessible represents only about $0.02 \%$ of the total water resources (Ademoroti, 1996a) and it is being stressed due to human activities.

The availability of good quality water is an indispensable feature for preventing water related diseases and improving quality of life. Natural water contains different types of impurities which are introduced into aquatic system by different ways such as weathering of rocks and leaching of soils, dissolution of aerosol particles from the atmosphere and from several human activities, including mining, processing and the use of metalbased materials (Asaolu et al., 1997; Adekola et al., 2010). The interactions of pollutants particularly the chemicals, with the natural properties of water are a major concern and have influenced its uses (Mustapha and Omotosho, 2005; Abdus-Salam et al., 2013). Natural water is said to be polluted when its physicochemical characteristics have been changed by humans such that it is no longer useful for its primary purpose (Ibe, 1988; Olajire and Imeokparia, 2000; Fatoki et al., 2002). Pollutants generally gain access into the river system from both natural and anthropogenic inputs thereby changing its physicochemical characteristics.

Heavy metals are among the most harmful of the elemental pollutants and are of particular concern because of their toxicities to man. They include essential elements such as $\mathrm{Fe}, \mathrm{Cu}, \mathrm{Zn}, \mathrm{Co}$ and $\mathrm{Mn}$, which are needed by biological systems while $C d$, As, $\mathrm{Hg}, \mathrm{Pb}$ and $\mathrm{Se}$ are toxic in all concentrations (Eddy et al., 2006). Most of them show significant affinity to sulfur and disrupt enzyme function by forming bonds with sulfur groups in enzymes (Adekola et al., 2010). Cadmium, copper, lead and mercury ions bind to the cell membranes hindering transport processes through the cell wall. Some of the metalloids are significant water pollutants (Manahan, 1999), they are non-biodegradable and have tendency to accumulate in global ecological circle, in which natural water serves as the main pathway (Adekola et al., 2003).
Aquatic ecosystem is the ultimate recipient of almost everything including heavy metals. There are various sources of heavy metals; some originate from anthropogenic activities like draining of sewerage, dumping of hospital wastes and recreational activities. Conversely, metals also occur in small amounts naturally and may enter into aquatic system through leaching of rocks, airborne dust, forest fires and vegetation (Fernandez and Olalla, 2000). As heavy metals cannot be degraded, they are continuously being deposited and incorporated in water, sediment and aquatic organisms, thus causing heavy metal pollution in water bodies (Linnik and Zubenko, 2000).

According to Ademoroti (1996a), the use of sediments as pollution indicators has some advantages over the use of water sample; this is due to the fact that the concentrations of harmful toxic substances are of many orders of magnitude higher in water sediments and biological tissues than water itself. Whereas the concentrations of metals in water may vary considerably depending on seasonal and annual fluctuations, the concentrations in sediment and biological indicators are fairly constant. The release of heavy metals from sediment or its bioavailability to aquatic organisms is a function of a number of variables such as the sediment characteristics, nature of the metals species, duration of contact between the metal and the adsorbing surface and the physicochemical properties of the water matrix (Iwegbue et al., 2007; Adekola et al., 2010).

Water quality describes the chemical, physical and biological characteristics of water in relation to all other hydrological properties, usually in respect to its suitability for a particular purpose. Any characteristics of water that affects its portability, the survival, reproduction, growth and production of aquaculture species, influences management decisions, causes environmental impacts or reduces product quality and safety can be considered a water quality variable (SAWQG, 1996; Iqbal et al., 2004). The values or concentrations attributed to water quality parameters can be used to describe the pollution 
status (SAWQG, 1996; Aiyesanmi, 2006). This study aimed at determining the physicochemical status of Agba, Igbaja, Oloru and Omu-Aran dams' water and sediments, compare them to international standards and determine the suitability of the dam for use in drinking. The study will also provide baseline data for future works on the dams.

\section{Materials and Methods Study area}

Four major dams spatially located in different Local Government Areas (LGA) in Kwara State were selected for the study. The dams include Agba dam (Ilorin south LGA), Igbaja dam (Ifelodun $L G A$ ), Omu-Aran dam (Irepodun LGA) and Oloru dam (Moro LGA). The selected dams provide a large percentage of the population in Kwara State with potable water after being treated. Three different sampling locations were spatially selected along each of the dam course. The water sample was collected for six consecutive months and the sediment was collected twice during this period. The sampling period cut across the rain and dry seasons of the year. Table 1 shows the dams coordinate descriptions.

Table 1: Sampling dam descriptions

\begin{tabular}{ll}
\hline Sampling dams & Location \\
\hline Agba dam & NO8 $^{\circ} 28.7928^{\prime} E 004^{\circ} 35.1608^{\prime}$ \\
Igbaja dam & $N^{\circ} 08^{\circ} 18.6891^{\prime} E 004^{\circ} 50.5737^{\prime}$ \\
Oloru dam & $N^{\circ} 38.7352^{\prime} E 004^{\circ} 34.5579^{\prime}$ \\
Omu-Aran dam & $N^{\circ} 08^{\circ} 08.6839^{\prime} E 004^{\circ} 34.5579^{\prime}$ \\
\hline
\end{tabular}

\section{Sampling and preservation}

The water samples were collected from three locations on each of the dam site at an interval of $3 \mathrm{~m}$ from each sampling point and at a depth of about $1 \mathrm{~m}$. The water were stored in a 2-L capacity plastic bottle previously cleaned by washing in nonionic detergent, rinsed with tap water and later soaked in $10 \% \mathrm{HNO}_{3}$ for 24 hours and finally rinsed with deionised water. All samples were acidified with $1.5 \mathrm{~mL}$ concentrated $\mathrm{HNO}_{3}$ per bottle in order to stabilize the metal ions and prevent precipitation while the temperature and $\mathrm{pH}$ was determined in- situ. Water samples for $D O$ and BOD measurements were collected separately with $300 \mathrm{~mL}$ BOD bottles.

The dam sediment was collected from locations where water samples were taking with the aid of a stainless bottom grab. The content of the grab was emptied into a black polythene bag at each location. Samples were immediately transported to the laboratory where loose particles and plants debris were removed manually from the sediment prior to chemical treatment. The sediment samples were air-dried in the laboratory before crushing with mortar to small particle sizes.

\section{Determination of Physicochemical parameters}

Water temperatures and $\mathrm{pH}$ were measured at each sampling location with the aid of mercury in glass thermometer and Hanna pocket sized $\mathrm{pH}$ meter respectively. The DO, BOD, alkalinity, total hardness, TS, TSS and TDS were determined by standard methods (Ademoroti, 1996b). The inorganic and non-metallic constituents (nitrate, chloride, phosphate, sulphate) analyses were all determined spectrophotometrically in the laboratory using standard procedures. Chloride, nitrate, sulphate, phosphate were determined by Mohr's, sodium salicylate (colorimetric), turbidometric and ascorbic acid methods respectively (Ademoroti, 1996b).

A $100 \mathrm{ml}$ portion of the acidified sample in $250 \mathrm{~mL}$ Erlenmeyer flask was digested for total metal contents. A $3 \mathrm{ml}$ portion of conc. $\mathrm{HNO}_{3}$ was added and then placed on a hot plate. It was slowly and cautiously evaporated to less than $5 \mathrm{ml}$ making sure that the sample does not boil and that no area of the bottom of the beaker is allowed to go dry. It was allowed to cool, then additional $5 \mathrm{ml}$ conc. $\mathrm{HNO}_{3}$ was added and the beaker was then covered with a watch glass and returned to hot plate. The temperature of the hot plate was increased so that a gentle reflux action occurs. It was evaporated to less than $5 \mathrm{ml}$ and then allowed to cool. A $10 \mathrm{ml}$ volume of $1 \mathrm{M} \mathrm{HCl}$ and $15 \mathrm{ml}$ of distilled water was added. It was heated for additional $15 \mathrm{~min}$ to dissolve any residue present and then cooled. The walls of the beaker and the watch glass were washed 
down with water and solution filtered to remove insoluble materials. The samples were then analyzed for $\mathrm{Cu}, \mathrm{Cd}, \mathrm{Zn}, \mathrm{Mn}$ and $\mathrm{Fe}$ using Atomic Absorption Spectrophotometer. Sediment samples were subjected to $B C R$ sequential extraction procedure (Nada et al., 2011) for understanding the fate of trace metals in terms of chemical species, mobility and availability in the water environment. The filtrates from the various stages of extraction were analyzed for metals released by atomic absorption spectrometry (AAS).

\section{Results and Discussion}

The results of the average monthly physicochemical parameters determined between the months of June-December 2014 in this study are presented in Table 2 for the four dams. The values in the parenthesis represent the range values for the entire sampling period. The $\mathrm{pH}$ value observed (Table 2) shows that the $\mathrm{pH}$ level for the dams fall within the W.H.O recommended range value of $6.5-8.5$. Water with low $\mathrm{pH}$ tends to be toxic and a high pH valueconfers a bitter taste on it (Muhammed et al., 2013). The temperature obtained (Table 2) showed that the dams' temperature ranges from $26.7^{\circ}$ to $28.7^{\circ} \mathrm{C}$ for Agba dam with a mean temperature of $27.3^{\circ} \mathrm{C} ; 23.0^{\circ}$ to $26.0^{\circ} \mathrm{C}$ for Igbaja dam with a mean temperature of $24.6^{\circ} \mathrm{C} ; 26.0^{\circ}$ to $27.8^{\circ} \mathrm{C}$ for Oloru dam with a mean temperature of $26.5^{\circ} \mathrm{C}$ and $24.0^{\circ}$ to $28.7^{\circ} \mathrm{C}$ for Omu-Aran dam with a mean temperature of $25.2^{\circ} \mathrm{C}$. The temperatures obtained are within the limit of WHO standard and therefore have no adverse effect on the aquatic environment. In an established system the water temperature controls the rate of all chemical reactions, affects fish growth, reproduction and immunity (Patil et al., 2012).

The dissolved oxygen (DO) (Table 2) contents ranges from 3.8 to $5.5 \mathrm{mg} / \mathrm{L}$ across the dams while the mean DO is $5.4 \mathrm{mg} / \mathrm{L}$ for Agba dam; $5.5 \mathrm{mg} / \mathrm{L}$ for Igbaja dam; $3.8 \mathrm{mg} / \mathrm{L}$ for Oloru dam and $5.1 \mathrm{mg} / \mathrm{L}$ for Omu-Aran dam. DO standard for drinking purpose is $6 \mathrm{mg} / \mathrm{L}$ whereas for sustaining fish and aquatic life is $4-5 \mathrm{mg} / \mathrm{L}$ (Rao, 2005). The DO values from this study were slightly lower than recommended standard for drinking water. Similar result was reported by Sangpal et al. (2011) on the research work carried out on Ujjani reservoir, India. $A$ healthy body of water should have $D O$ value that is not less than $5.2 \mathrm{mg} \mathrm{O} / \mathrm{L}$ while high values may pose challenge and stress to fish in the environment (Asia and Akpornor, 2007; Ehiagbonare and Ogunride, 2010). From Table 2, BOD values range from 1.1 to $1.8 \mathrm{mg} / \mathrm{L}$ across the dams while the mean BOD is $1.7 \mathrm{mg} / \mathrm{L}$ for Agba dam, $1.8 \mathrm{mg} / \mathrm{L}$ for Igbaja dam; $1.1 \mathrm{mg} / \mathrm{L}$ for Oloru dam and $1.7 \mathrm{mg} / \mathrm{L}$ for OmuAran dam. The BOD is observed to be higher during the raining season (June and July) than the dry season (October and December). This means that the water body contains some biodegradable dead plant matter that were visible throughout the entire length and breadth of the dam, as well as decomposing waste input through runoff into the dams (IEPA, 2001). The BOD level for the dams is within WHO limits for drinking water. The results are in agreement with that obtained by Himrangshu et al., (2012). BOD is the parameter used to measure the activities of bacteria in stabilizing the decomposable organic matter which is aimed at determining the amount of biochemically oxidisable carbonaceous matter (Gupta et al., 2003).

Hard water is characterized with high mineral contents that are usually not harmful to humans. According to World Health Organization (WHO), the upper limit of hardness of water is $500 \mathrm{mg} / \mathrm{L}$. From Table 2 hardness ranges from 0.48 to 0.69 $\mathrm{mg} / \mathrm{L}$ across the dams while the means are 0.69 $\mathrm{mg} / \mathrm{L}$ for Agba dam, $0.57 \mathrm{mg} / \mathrm{L}$ for Igbaja dam, 0.56 $\mathrm{mg} / \mathrm{L}$ for Oloru dam, and $0.48 \mathrm{mg} / \mathrm{L}$ for Omu-Aran dam. These results show clearly that hardness of the dams' water is within the WHO standards and it is not harmful for local inhabitants. Water has been classified on the basis of hardness as follows: water having $0.75 \mathrm{mg} / \mathrm{L} \mathrm{CaCO}_{3}$ as soft, $75-150 \mathrm{mg} / \mathrm{L}$ $\mathrm{CaCO}_{3}$ as hard and $>300 \mathrm{mg} / \mathrm{L} \mathrm{CaCO}_{3}$ as total hardness (Adeyeye and Abulude, 2004). Based on this, the dam water is classified as soft water. The alkalinity of dams water ranges from 81.1 to 141.8 $\mathrm{mg} / \mathrm{L}$ across the dams while the mean value of 141.8 $\mathrm{mg} / \mathrm{L}$ for Agba dam, $101.8 \mathrm{mg} / \mathrm{L}$ for Igbaja dam, $109.8 \mathrm{mg} / \mathrm{L}$ for Oloru dam, $81.1 \mathrm{mg} / \mathrm{L}$ in Omu-Aran dam. A range of 98 to $116 \mathrm{mg} / \mathrm{L}$ of total alkalinity 
Table 2: Average values of the physicochemical parameters of water samples of some dams in Kwara state, Nigeria from June to December 2014

\begin{tabular}{ccccc}
\hline Parameters & Agba dam & Igbaja dam & Oloru dam & Omu-Aran dam \\
\hline pH & 7.9 & 7.0 & 7.2 & 7.2 \\
Temp & $(6.9-9.2)$ & $(6.1-7.6)$ & $(6.5-8.0)$ & $(6.6-7.7)$ \\
& 27.3 & 24.6 & 26.5 & 25.2 \\
DO (mg/l) & $(26.7-28.7)$ & $(23-26)$ & $(26-27.8)$ & $(24-28.7)$ \\
& 5.4 & 5.5 & 3.8 & 5.1 \\
BOD(mg/l) & $(1.5-9.5)$ & $(1.8-9.5)$ & $(1-6.7)$ & $(1.3-9.5)$ \\
& 1.7 & 1.8 & 1.1 & 1.7 \\
TDS (mg/l) & $(0.3-3.3)$ & $(0.7-3.9)$ & $(0.3-2.4)$ & $(0.4-3.4)$ \\
& 141.7 & 96.1 & 120 & 81.7 \\
T. Hardness & $(50-220)$ & $(53.3-126.7)$ & $(26.6-176.7)$ & $(33.3-213.3)$ \\
(mg/l) & 0.69 & 0.57 & 0.56 & 0.48 \\
Alkalinity (mg/l) & $(0.56-1.08)$ & $(0.33-1.09)$ & $(0.33-1.07)$ & $(0.31-0.92)$ \\
& 141.8 & 101.8 & 109.8 & 81.1 \\
& $(124.5-182.2)$ & $(88.9-106.7)$ & $(93.3-115.6)$ & $(63.3-91.1)$ \\
\hline
\end{tabular}

Values in the parenthesis are the range of values. Temp $=$ Temperature; $D O=$ Dissolved oxygen; $B O D=$ Biochemical oxygen demand; TDS = Total dissolved solids and T. Hardness $=$ Total hardness

was reported in Kathralu pond water near Chitradurga, Karnataka, India (Banker et al. 2010). Thus, these values were within the permissible limit of WHO standards (200 $\mathrm{mg} / \mathrm{L})$ and may not cause health related problems. From Table 2 the TDS for all the dams have no violation of WHO standards of $500 \mathrm{mg} / \mathrm{L}$. The TDS of dams water ranges from 81.7 to $141.7 \mathrm{mg} / \mathrm{L}$ while the mean value of $141.7 \mathrm{mg} / \mathrm{L}$ for Agba dam, $96.1 \mathrm{mg} / \mathrm{L}$ for Igbaja dam, $120 \mathrm{mg} / \mathrm{L}$ for Oloru dam and $81.7 \mathrm{mg} / \mathrm{L}$ for Omu-Aran dam. Quadri et al. (2010) had reported a range of 0.1 to $103 \mathrm{mg} / \mathrm{L}$ of TDS in Bindusara dam of Beed, Maharashtra, India, while Sayyed et al. (2012) reported range of 160 to $268 \mathrm{mg} / \mathrm{L}$ of TDS in Limboti dam Maharashtra. The values obtained here are within the WHO standard and do not pose threat to man and aquatic life.

Chloride concentration (Table 3) ranges from 73.3 to $166.7 \mathrm{mg} / \mathrm{L}$ with mean value of $111.1 \mathrm{mg} / \mathrm{L}$ in Agba dam, 53.3-113.3 mg/L with mean value of $77.8 \mathrm{mg} / \mathrm{L}$ in Igbaja dam, 53.3 to $106.7 \mathrm{mg} / \mathrm{L}$ with mean value of $80 \mathrm{mg} / \mathrm{l}$ in Oloru dam, and from 46.7 to 106.6 $\mathrm{mg} / \mathrm{L}$ with mean value of $78.9 \mathrm{mg} / \mathrm{L}$ in Omu-Aran dam. These concentrations of chloride are within the guideline values of the WHO standard.
According to WHO (2006), chloride concentration in excess of $250 \mathrm{mg} / \mathrm{L}$ may give rise to detectable taste in water. Chloride has little effect on fish health or behavior and is not considered a problem in inland waters (SAWQG, 1996). The sulphate concentration (Table 3) ranges from 28 to 466.7 $\mathrm{mg} / \mathrm{L}$ with mean value of $242.6 \mathrm{mg} / \mathrm{L}$ in Agba dam, 161.3 to $582.7 \mathrm{mg} / \mathrm{L}$ with mean value of $314.1 \mathrm{mg} / \mathrm{L}$ in Igbaja dam, 205.3 to $1082.7 \mathrm{mg} / \mathrm{L}$ with mean value of $705.2 \mathrm{mg} / \mathrm{L}$ in Oloru dam and 60.7 to $624 \mathrm{mg} / \mathrm{L}$ with mean value of $309.1 \mathrm{mg} / \mathrm{L}$ in Omu-Aran. Most of these values fall within $\mathrm{WHO}$ permissible limits for drinking water $(500 \mathrm{mg} / \mathrm{L})$ with the exception of Oloru. A high level of sulphate (above $250 \mathrm{mg} / \mathrm{L}$ ) in drinking water may lead to diarrhea as well as causing detectable taste and odour (USEPA, 2002). With the exception to Agba, Igbaja and Omu-Aran dams, the Oloru dam is a source of health concern. According to USEPA (2002), phosphate concentration in reservoirs must not exceed 0.025 $\mathrm{mg} / \mathrm{L}$ in order to control algae growth. Phosphate concentration (Table 3 ) ranges from 4.40 to 5.15 $\mathrm{mg} / \mathrm{L}$ with mean value of $4.64 \mathrm{mg} / \mathrm{L}$ in Agba dam, 4.39 to $5.69 \mathrm{mg} / \mathrm{L}$ with mean value of $5 \mathrm{mg} / \mathrm{L}$ in Igbaja dam, 4.57 to $5.89 \mathrm{mg} / \mathrm{L}$ with mean value of 
Table 3: Concentrations of some nutrients and heavy metals in some dams in Kwara state, Nigeria from June - December 2014

\begin{tabular}{ccccc}
\hline Parameters & Agba dam & Igbaja dam & Oloru dam & Omu-Aran dam \\
\hline $\mathrm{Cl}^{-}(\mathrm{mg} / \mathrm{l})$ & 111.1 & 77.8 & 80 & 78.9 \\
& $(73.3-166.7)$ & $(53.3-113.3)$ & $(53.3-106.7)$ & $(46.7-106.7)$ \\
$\mathrm{SO}_{4}{ }^{2-}(\mathrm{mg} / \mathrm{l})$ & 242.6 & 314.1 & 705.2 & 309.1 \\
& $(28-484.7)$ & $(161.3-582.7)$ & $(205.3-1082.7)$ & $(60.7-624)$ \\
$\mathrm{PO}_{4}{ }^{3-}(\mathrm{mg} / \mathrm{l})$ & 4.64 & 5.0 & 5.17 & 4.93 \\
& $(4.4-5.15)$ & $(4.39-5.69)$ & $(4.57-5.89)$ & $(4.43-5.59)$ \\
$\mathrm{NO}_{3}{ }^{-}(\mathrm{mg} / \mathrm{l})$ & 9.6 & 4.6 & 8.35 & 10.7 \\
& $(0.19-36.63)$ & $(0.02-16.25)$ & $(0.2-23.7)$ & $(0.15-26.11)$ \\
$\mathrm{Cu}(\mathrm{mg} / \mathrm{l})$ & 0.11 & 0.14 & 0.14 & 0.17 \\
& $(0.07-0.19)$ & $(0.07-0.24)$ & $(0.08-0.22)$ & $(0.1-0.33)$ \\
$\mathrm{Cd}(\mathrm{mg} / \mathrm{l})$ & 0.06 & 0.05 & 0.04 & 0.05 \\
& $(0.04-0.08)$ & $(0.02-0.08)$ & $(0.02-0.07)$ & $(0.04-0.08)$ \\
$\mathrm{Zn}(\mathrm{mg} / \mathrm{l})$ & 0.84 & 0.96 & 0.71 & 0.57 \\
& $(0.56-1.29)$ & $(0.41-1.61)$ & $(0.3-0.8)$ & $(0.42-0.76)$ \\
$\mathrm{Mn}(\mathrm{mg} / \mathrm{l})$ & 1.44 & 2.01 & 1.28 & 1.42 \\
& $(0.39-3.17)$ & $(0.18-6.07)$ & $(0.41-2.41)$ & $(0.22-4.22)$ \\
$\mathrm{Fe}(\mathrm{mg} / \mathrm{l})$ & 1.49 & 7.45 & 8.75 & 5.5 \\
& $(0.95-2.46)$ & $(3.27-12.79)$ & $(4.39-13.95)$ & $(3.19-8.27)$ \\
\hline
\end{tabular}

Values in the parenthesis are the range of values. $\mathrm{Cl}^{-}=$Chloride ion; $\mathrm{SO}_{4}{ }^{2-}=$ Sulphate ion; $\mathrm{PO}_{4}{ }^{3-}=$ Phosphate ion: $\mathrm{NO}_{3}{ }^{-}=$Nitrate ion; $\mathrm{Cu}=$ Copper; $\mathrm{Cd}=$ Cadmium; $\mathrm{Zn}=\mathrm{Zinc} ; \mathrm{Mn}=$ Manganese and Fe = Iron

$5.17 \mathrm{mg} / \mathrm{L}$ in Oloru dam and from 4.43 to $5.59 \mathrm{mg} / \mathrm{L}$ with mean value of $4.93 \mathrm{mg} / \mathrm{L}$ in Omu-Aran dam. The high level of phosphate in the sampled water may be due to effect of agricultural run-off (Nagendrappa et al., 2007). Natural-dissolved phosphates are considered to be largely non-toxic, although certain man - made organophosphates do have toxic effects. It is, however, likely that high concentrations of dissolved phosphate may lead to osmotic stress, as is the case with high nitrate concentrations (SAWQG, 1996). Nitrate, the final product of nitrification plays an important role as the major nutrient to phytoplanktons that later died off and settled down on the sediment (Daniel and Egila, 2011). The nitrate concentration (Table 3 ) ranges from 0.19 to $36.63 \mathrm{mg} / \mathrm{L}$ with mean value of $9.6 \mathrm{mg} / \mathrm{L}$ in Agba dam, 0.02 to $16.25 \mathrm{mg} / \mathrm{L}$ with mean value of $4.6 \mathrm{mg} / \mathrm{L}$ in Igbaja dam, 0.2 to $23.70 \mathrm{mg} / \mathrm{L}$ with mean value of $8.35 \mathrm{mg} / \mathrm{L}$ in Oloru dam and 0.15 to 26.11 $\mathrm{mg} / \mathrm{L}$ with mean value of $10.7 \mathrm{mg} / \mathrm{L}$ in Omu-Aran dam. The nitrate concentration obtained from all the dams falls within the WHO standards of $50 \mathrm{mg} / \mathrm{L}$ for drinking water and therefore pose no threat on the health of consumers. High values obtained during the month of December in all the dams may be due to re-dissolution from bottom sediment, and/or dry season farming practice noticeable around the dams. Whenever there is nitrate contamination of drinking water, it poses a severe risk to infants due to its interference with blood oxygen transport and when such water is boiled, it only concentrates nitrate further (Bothkin and Edward, 1997).

Copper is an essential substance to human life, but in high doses it can cause anaemia, liver and kidney damage, and stomach and intestinal irritation. Copper normally occurs in drinking water from copper pipes, as well as from additives designed to control algae growth (Gomez-Ariza et al., 2000). Copper has been classified as one of the essential elements required by man to promote activity of enzyme systems in human body. However: it becomes toxic to man when ingested in excess of tolerable limit (NIS, 2007). The concentrations of 
copper ranges from 0.07 to $0.19 \mathrm{mg} / \mathrm{L}$ with mean value of $0.11 \mathrm{mg} / \mathrm{L}$ in Agba dam, 0.07 to $0.24 \mathrm{mg} / \mathrm{L}$ with mean value of $0.14 \mathrm{mg} / \mathrm{L}$ in Igbaja dam, 0.08 to $0.22 \mathrm{mg} / \mathrm{L}$ with mean value of $0.14 \mathrm{mg} / \mathrm{L}$ in Oloru dam and from 0.1 to $0.33 \mathrm{mg} / \mathrm{L}$ with mean value of 0.17 $\mathrm{mg} / \mathrm{L}$ in Omu-Aran dam (Table 3). These concentrations are well below the WHO maximum limit of acceptability level of $2.0 \mathrm{mg} / \mathrm{L}$ in drinking water. Cadmium concentration ranges from 0.04 to $0.08 \mathrm{mg} / \mathrm{L}$ with mean value of $0.06 \mathrm{mg} / \mathrm{L}$ in Agba dam, 0.02 to $0.08 \mathrm{mg} / \mathrm{L}$ with mean value of $0.05 \mathrm{mg} / \mathrm{L}$ in Igbaja dam, 0.02 to $0.07 \mathrm{mg} / \mathrm{L}$ with mean value of $0.04 \mathrm{mg} / \mathrm{L}$ in Oloru dam and from 0.04 to $0.08 \mathrm{mg} / \mathrm{L}$ with mean value of $0.05 \mathrm{mg} / \mathrm{L}$ in Omu-Aran dam. The results obtained here are higher than that reported by Samir and Ibrahim (2008) on the assessement of heavy metals pollution in water and sediments and their effects on Oreochromis niloticus in the northern delta lakes, Egypt and higher than the permissible limit recommended by WHO but lower than what was reported by Abdel-Baky et al. (1998) on the environmental impact assessment of pollution in lake Manzala, Egypt. The high level of $\mathrm{Cd}$ in water can be attributed to industrial and agricultural discharges (Mason, 2002). The latter is more probable as dry and wet season farming take place along the river course that were dam. Cadmium is a by-product of the mining and smelting of lead and zinc. It is used in nickel cadmium batteries, PVC plastic and paint pigments (Eaton, 2005). It can be found in soils because insecticides, fungicides, sludge, and commercial fertilizers that are formulated with cadmium are used in agriculture. Cadmium may be found in reservoirs containing shell fish. The level of $C d$ observed in each of the dam is a source of environmental concern, as this could cause health related problems.

Zinc is essential to man but if ingested in large amounts it has an emetic effect. However, the concern for its level in water supply is not in regard to toxicity but taste, and quite high levels are permissible (WHO, 1993). It has been found that various parts of the body contain zinc; relatively high concentrations are present in the skin, while the visceral organs contain approximately 30-50 $\mu \mathrm{g} / \mathrm{g}$ in fresh tissue. Most of the body zinc are in the bones where its concentration is approximately $200 \mu \mathrm{g} \mathrm{Zn/g}$. Excessive intake of $\mathrm{Zn}$ may lead to vomiting, abdominal pains, nausea, lethargy and dehydration (ATSDR, 1994). The concentration of zinc (Table 3) ranges from 0.56 to $1.29 \mathrm{mg} / \mathrm{L}$ with mean value of $0.84 \mathrm{mg} / \mathrm{l}$ in Agba dam, 0.41 to 1.44 $\mathrm{mg} / \mathrm{L}$ with mean value of $0.96 \mathrm{mg} / \mathrm{L}$ in Igbaja dam, 0.3 to $0.72 \mathrm{mg} / \mathrm{L}$ with mean value of $0.71 \mathrm{mg} / \mathrm{L}$ in Oloru dam and 0.42 to $0.76 \mathrm{mg} / \mathrm{L}$ with mean value of $0.57 \mathrm{mg} / \mathrm{L}$ in Omu-Aran dam. The concentrations of zinc in all the dams fall within the WHO permissible limit (3 $\mathrm{mg} / \mathrm{L}$ ) for drinking water. Manganese is one of the essential nutrient elements required for the growth and well-being of plants and animals. Water body containing excessive level of $\mathrm{Mn}$ may impair objectionable staining properties on cloth washing operations. Manganese has no particular toxicological connotations; the objections to manganese like iron are aesthetic factors (WHO, 1993). According to WHO (2006), the presence of manganese in drinking water may be objectionable to consumers if it is deposited in water mains and causes water discolouration. Manganese in this study (Table 3) ranges from 0.39 to $3.17 \mathrm{mg} / \mathrm{L}$ with mean value of $1.44 \mathrm{mg} / \mathrm{L}$ in Agba dam, 0.18 to 6.07 $\mathrm{mg} / \mathrm{L}$ with mean value of $2.01 \mathrm{mg} / \mathrm{L}$ in Igbaja dam, 0.41 to $2.41 \mathrm{mg} / \mathrm{L}$ with mean value of $1.28 \mathrm{mg} / \mathrm{L}$ in Oloru dam and 0.22 to $4.22 \mathrm{mg} / \mathrm{L}$ with mean value of $1.42 \mathrm{mg} / \mathrm{L}$ in Omu-Aran dam. The obtained results are higher than that of Abdus-Salam et al. (2013) on Owalla dam, Osun state, Nigeria. Comparing the results obtained here with the WHO standards (0.4 $\mathrm{mg} / \mathrm{L}$ ), it shows clearly that all the dams violated the limit and is therefore a source of concern for the consumers.

Iron concentration ranges from 0.95 to 2.46 $\mathrm{mg} / \mathrm{L}$ with mean value of $1.49 \mathrm{mg} / \mathrm{L}$ in Agba dam, 3.27 to $12.79 \mathrm{mg} / \mathrm{L}$ with mean value of $7.45 \mathrm{mg} / \mathrm{L}$ in Igbaja dam, 4.75 to $13.95 \mathrm{mg} / \mathrm{L}$ with mean value of $8.75 \mathrm{mg} / \mathrm{L}$ in Oloru dam and from 3.19 to $8.27 \mathrm{mg} / \mathrm{L}$ with mean value of $5.5 \mathrm{mg} / \mathrm{L}$ in Omu-Aran. The concentrations of iron in this study are high compared to that reported by Abdus-Salam et al. (2013) on Owalla dam. These values are above the permissible limit for drinking water standards of WHO. Most importantly, the high level of iron 
content in the water has no identifiable point source though, it has been reported that iron occurs at high levels in Nigerian soils and could manifest in surface waters that flow over them (Aiyesanmi, 2006). The WHO (1996) declared that iron in water above 3 $\mathrm{mg} / \mathrm{L}$ may pose aesthetic problem and also promote undesirable bacterial growth (iron bacteria) within a waterworks and distribution system, resulting in the deposition of a slimy coating on the piping. The concentration of the analyzed heavy metals in the water for all the four dams in $\mathrm{mg} / \mathrm{L}$ was in the order of $\mathrm{Fe}>\mathrm{Mn}>\mathrm{Zn}>\mathrm{Cu}>\mathrm{Cd}$. The presence of these metals in natural waters is a combination of contributions from weathering of rocks and minerals, dumping of refuse on water course and farming activities (Aiyesanmi, 2006; Adefemi et al., 2007). The order of these analyzed heavy metals in this study is in agreement with work done by Adakole et al. (2008) on the assessment of water quality of a man-made lake in Zaria, Nigeria.

The mean concentrations of heavy metals in the sequential extraction of sediments for the months of August, 2014 and September, 2014 are presented in Tables 4 and 5 respectively. These Tables provided information on the four fractions (exchangeable + acid + water soluble; reducible; oxidisable; and residual) into which the metals were fractionated. Metals in the residual fraction are the least mobile and pose no threat to environment. The average of metals concentrations for the sequential extraction in the sediments are shown in Table 6. The concentrations of heavy metals in the sediments are higher than those present in water. This is expected to be so as sediments generally act as scavengers and banks for heavy metals (Helmke et al., 1977). In general, metal content in sediments is an indication of extent of pollution and it provides an understanding into the interaction between the sediment matrix and flowing water (Adekola et al., 2010); it is the source of and the uptake by benthic organisms as it solubilises depending on the conditions of $\mathrm{pH}$ and temperature (Ogoyi et al., 2011). The mobility order and the availability of the metals were determined from the sequential extraction of the sediment filtrate. The bioavailability and non-bioavailability of metals for each dam are represented graphically in Fig. 1 for pictorial comparison. These metals are grouped (Table 7) into bioavailable (fractions of metals bound to exchangeable and reducible or oxides of $\mathrm{Mn}$ and $\mathrm{Fe}$ ) and non-bioavailable (metals bound to organic or oxidisable and residual fractions) on the basis of relative mobility between sediment and water as well as toxicity to aquatic environment (Adekola et al., 2010). Most of the metals studied $(\mathrm{Cu}, \mathrm{Cd}, \mathrm{Mn}, \mathrm{Zn}$ and $\mathrm{Fe}$ ) are mainly associated with the non- bioavailable while $M n$ and $Z n$ are mainly associated with bioavailable fractions of the sediments. A little change in the thermodynamic conditions of the bottom sediment will readily release bioavailable metals into water. Therefore, these dams are prone to aesthetic rather than health related problems on the basis of these metals. The bioavailable fraction represents the fraction that when the right $\mathrm{pH}$ and redox conditions are favourable, the metal ions will be soluble and can be taken up by aquatic plants or ingested by animals (Adekola et al., 2010). The trend observed in this study revealed that most of the metals were predominantly associated to the residual fraction and thus of low mobility. These results are in agreement with those of Howari and Banat (2001) on Yarmouk and Jordan rivers. The bioavailability of metals in the dams follows the trend $\mathrm{Mn}>\mathrm{Zn}>\mathrm{Cd}>\mathrm{Fe}>\mathrm{Cu}$ with exception of $\mathrm{Fe}$ and $\mathrm{Cu}$ interchanged in Agba dam; with copper contributing more. The bioavailable metals observed in this study are low compared to that which was reported by Adekola et al. (2010) on Kainji Lake sediments (Nigeria). With exception of Mn which occurs mainly in bioavailable form in all the dams, all other metals are found majorly in the nonbioavailable form in the sediments of the dams.

The Geoaccumulation index value of heavy metals in dams' sediment were calculated and reported in Table 8 . Geoaccumulation index, $I_{\text {geo, }}$ which was introduced by Muller (1979) is used to compare present day heavy metal concentrations with background values in order to quantify the extent and degree of metal pollution in aquatic 
Table 4: Metal ions concentrations in the sequential fractions of sediments in some dams in Kwara state, Nigeria for the month of August, 2014.

\begin{tabular}{lllllll}
\hline Dam & Fractions & $\begin{array}{l}\mathrm{Cu} \\
(\mathrm{mg} / \mathrm{kg})\end{array}$ & $\begin{array}{l}\mathrm{Cd} \\
(\mathrm{mg} / \mathrm{kg})\end{array}$ & $\begin{array}{l}\mathrm{Zn} \\
(\mathrm{mg} / \mathrm{kg})\end{array}$ & $\begin{array}{l}\mathrm{Mn} \\
(\mathrm{mg} / \mathrm{kg})\end{array}$ & $\begin{array}{l}\mathrm{Fe} \\
(\mathrm{mg} / \mathrm{kg})\end{array}$ \\
\hline Agba & Exchangeable + acid + water soluble & 0.06 & 0.03 & 1.45 & 5.05 & 2.03 \\
& Reducible & 0.08 & 0.06 & 1.68 & 4.76 & 92.69 \\
& Oxidisable & 0.33 & 0.02 & 0.2 & 0.35 & 0.38 \\
& Residual & 0.99 & 0.3 & 3.8 & 2.88 & 657.71 \\
Igbaja & Exchangeable + acid + water soluble & 0.08 & 0.03 & 1.32 & 17.76 & 6.6 \\
& Reducible & 0.07 & 0.07 & 1.77 & 5.78 & 139.08 \\
& Oxidisable & 0.23 & 0.04 & 0.32 & 0.2 & 0.8 \\
& Residual & 1.29 & 0.19 & 2.61 & 2.01 & 523.34 \\
Oloru & Exchangeable + acid + water soluble & 0.3 & 0.07 & 4.09 & 10.57 & 1.79 \\
& Reducible & 0.39 & 0.24 & 3.07 & 12.56 & 170.67 \\
& Oxidisable & 0.35 & 0.01 & 0.21 & 0.31 & 0.61 \\
& Residual & 2.11 & 0.44 & 4.35 & 3.33 & 684.11 \\
Omu-Aran & Exchangeable + acid + water soluble & 0.1 & 0.03 & 4.6 & 21.18 & 27.96 \\
& Reducible & 0.13 & 0.13 & 3.18 & 3.14 & 381.89 \\
& Oxidisable & 0.86 & 0.03 & 0.17 & 0.21 & 0.9 \\
& Residual & 2.24 & 0.29 & 3.38 & 3.68 & 1475.72 \\
\hline
\end{tabular}

$\mathrm{Cu}=$ copper; $\mathrm{Cd}=$ cadmium; $\mathrm{Zn}=$ zinc; $M n=$ manganese and $\mathrm{Fe}=$ iron

Table 5: Metal ions concentrations in the sequential fractions of sediments in some dams in Kwara state, Nigeria for the month of September, 2014.

\begin{tabular}{lllllll}
\hline Dam & Fractions & $\begin{array}{l}\mathrm{Cu} \\
(\mathrm{mg} / \mathrm{kg})\end{array}$ & $\begin{array}{l}\mathrm{Cd} \\
(\mathrm{mg} / \mathrm{kg})\end{array}$ & $\begin{array}{l}\mathrm{Zn} \\
(\mathrm{mg} / \mathrm{kg})\end{array}$ & $\begin{array}{l}\mathrm{Mn} \\
(\mathrm{mg} / \mathrm{kg})\end{array}$ & $\begin{array}{l}\mathrm{Fe} \\
(\mathrm{mg} / \mathrm{kg})\end{array}$ \\
\hline Agba & Exchangeable + acid + water soluble & 0.08 & 0.07 & 1.79 & 5.16 & 2.45 \\
& Reducible & 0.09 & 0.05 & 1.75 & 3.85 & 35.17 \\
& Oxidisable & 0.62 & 0.03 & 0.16 & 1.1 & $\begin{array}{l}0.38 \\
\text { Igbaja }\end{array}$ \\
& Residual & 1.32 & 0.27 & 3.59 & 3.93 & 780.29 \\
& Exchangeable + acid + water soluble & 0.06 & 0.06 & 1.30 & 5.74 & 3.16 \\
& Reducible & 0.07 & 0.06 & 1.67 & 5.96 & 93.59 \\
& Oxidisable & 0.36 & 0.03 & 0.16 & 0.35 & 0.94 \\
& Residual & 1.27 & 0.26 & 3.92 & 2.48 & 278.17 \\
& Exchangeable + acid + water soluble & 0.03 & 0.03 & 1.59 & 6.47 & 0.99 \\
& Reducible & 0.08 & 0.06 & 2.0 & 5.12 & 37.45 \\
& Oxidisable & 0.26 & 0.03 & 0.24 & 0.25 & 0.47 \\
& Residual & 1.11 & 0.29 & 2.54 & 2.15 & 315.89 \\
& Exchangeable + acid + water soluble & 0.13 & 0.06 & 3.34 & 14.89 & 19.76 \\
& Reducible & 0.15 & 0.1 & 2.45 & 2.63 & 197.89 \\
& Oxidisable & 0.55 & 0.1 & 0.16 & 0.21 & 0.52 \\
& Residual & 1.98 & 0.25 & 2.72 & 3.91 & 818.01 \\
\hline
\end{tabular}

$\mathrm{Cu}=$ copper; $\mathrm{Cd}=$ cadmium; $\mathrm{Zn}=$ zinc; $M n=$ manganese and $\mathrm{Fe}=$ iron 
Table 6: Average concentrations of the heavy metals in sediments of some dams in Kwara state, Nigeria for the month of August 2014 and September 2014 of the Dams

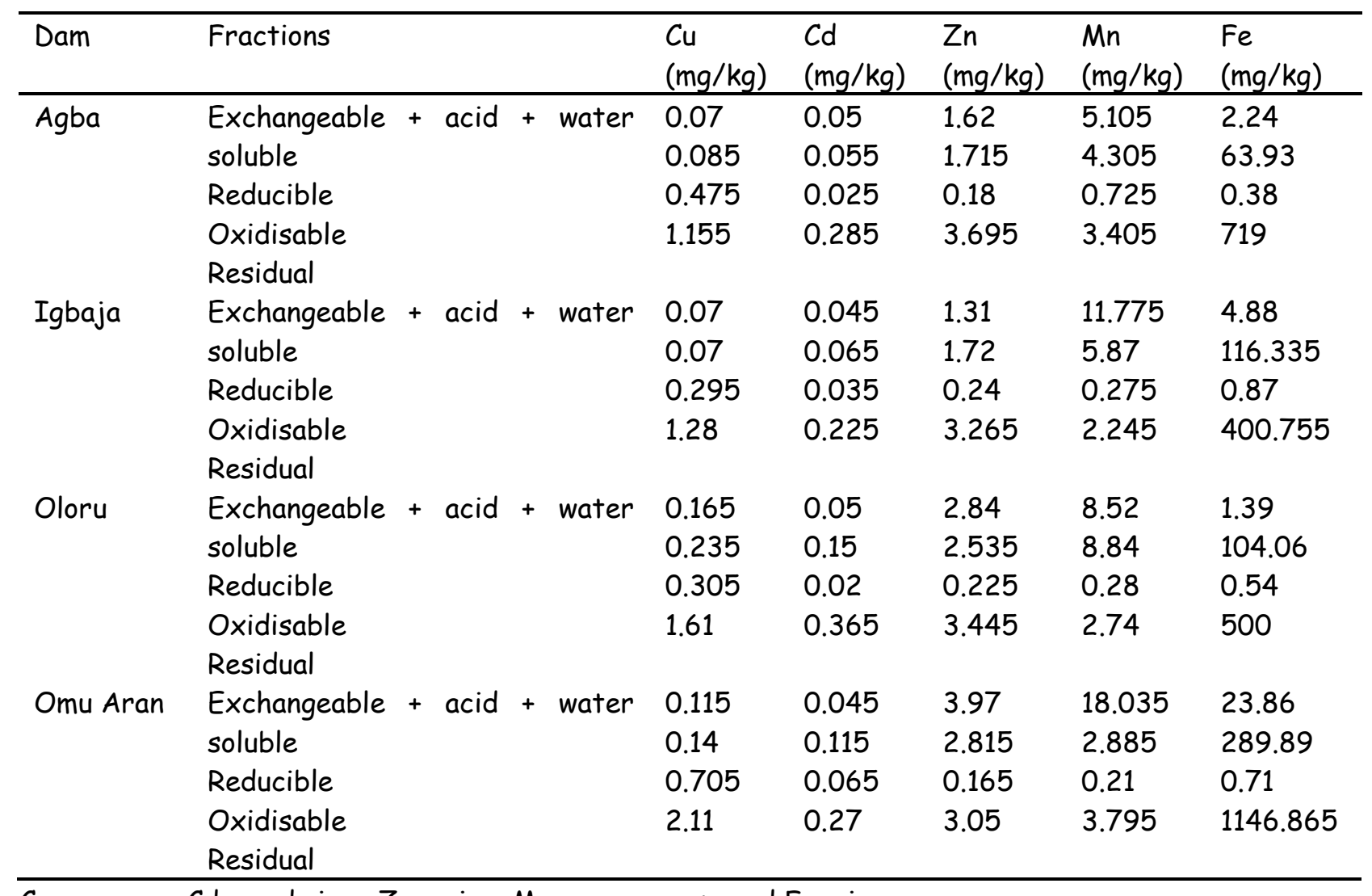

$C u=$ copper; $C d=$ cadmium; $\mathrm{Zn}=$ zinc; $M n=$ manganese and $F e=$ iron

Table 7: Percentage concentration level of bioavailable and non-bioavailable fractions of the sediment samples in some dams in Kwara state, Nigeria for the month of August, 2014 and September, 2014

\begin{tabular}{lllllll}
\hline Dam & Fractions & $\mathrm{Cu}(\%)$ & $\mathrm{Cd}(\%)$ & $\mathrm{Zn}(\%)$ & $\mathrm{Mn}(\%)$ & $\mathrm{Fe}(\%)$ \\
\hline Agba & Bioavailable & 8.68 & 25.30 & 46.26 & 69.50 & 8.42 \\
& Non-bioavailable & 91.32 & 74.70 & 53.74 & 30.50 & 91.58 \\
Igbaja & Bioavailable & 8.16 & 29.73 & 46.37 & 87.50 & 23.18 \\
& Non-bioavailable & 91.84 & 70.27 & 53.63 & 12.50 & 76.82 \\
Oloru & Bioavailable & 17.28 & 34.19 & 59.43 & 85.18 & 17.40 \\
& Non-bioavailable & 82.72 & 65.81 & 40.57 & 14.82 & 82.60 \\
& & & & & & \\
\multirow{2}{*}{ Omu-Aran } & Bioavailable & 8.31 & 32.32 & 67.85 & 83.93 & 21.47 \\
& Non-bioavailable & 91.69 & 67.68 & 32.15 & 16.07 & 78.53 \\
\hline
\end{tabular}

$C u=$ copper; $C d=$ cadmium; $Z n=$ zinc; $M n=$ manganese and $F e=$ iron 
Table 8: Geoaccumulation index value of heavy metals in the sediments of some dams in Kwara state, Nigeria.

\begin{tabular}{|c|c|c|c|c|c|}
\hline & $\mathrm{Cu}$ & $C d$ & $\mathrm{Zn}$ & $M n$ & $\mathrm{Fe}$ \\
\hline Agba dam & -5.24 & -0.12 & -.4 .31 & -6.56 & -6.46 \\
\hline $\begin{array}{c}\text { Igbaja } \\
\text { dam }\end{array}$ & -5.30 & -0.28 & -4.45 & -5.98 & -7.04 \\
\hline Oloru dam & -4.87 & 0.38 & -3.98 & -5.97 & -6.83 \\
\hline $\begin{array}{c}\text { Omu-Aran } \\
\text { dam }\end{array}$ & -4.46 & 0.14 & -3.83 & -5.68 & -5.56 \\
\hline
\end{tabular}

$\mathrm{Cu}=$ copper $\mathrm{Cd}=$ cadmium; $\mathrm{Zn}=$ zinc; $M n=$ manganese and $\mathrm{Fe}=$ iron

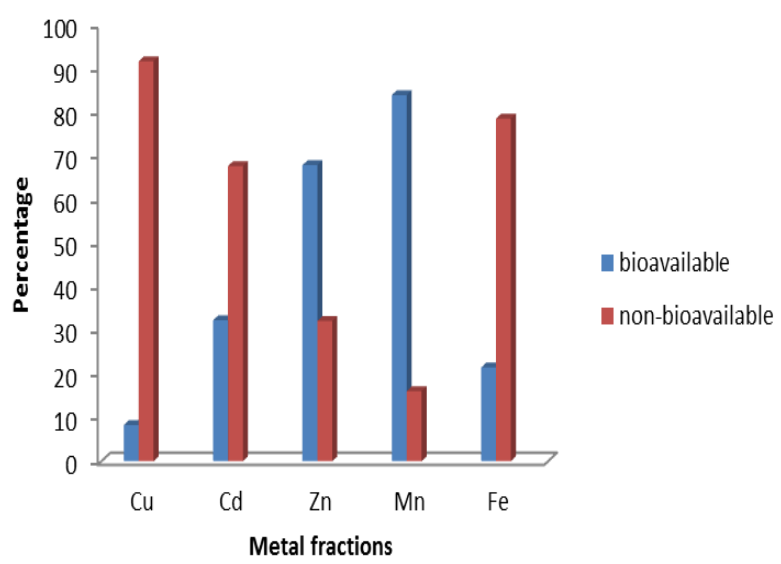

Figure 1a: Bioavailability level of metals in Oloru dam sediment

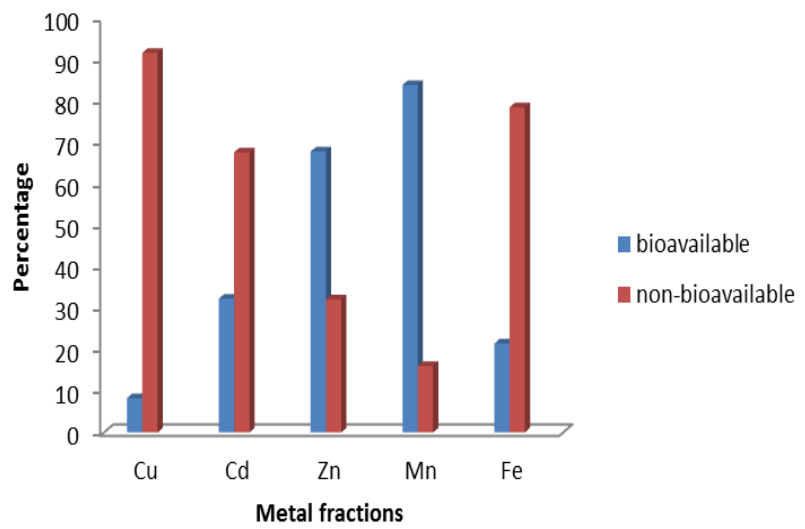

Figure 1b: Bioavailability level of metals in Igbaja dam sediment

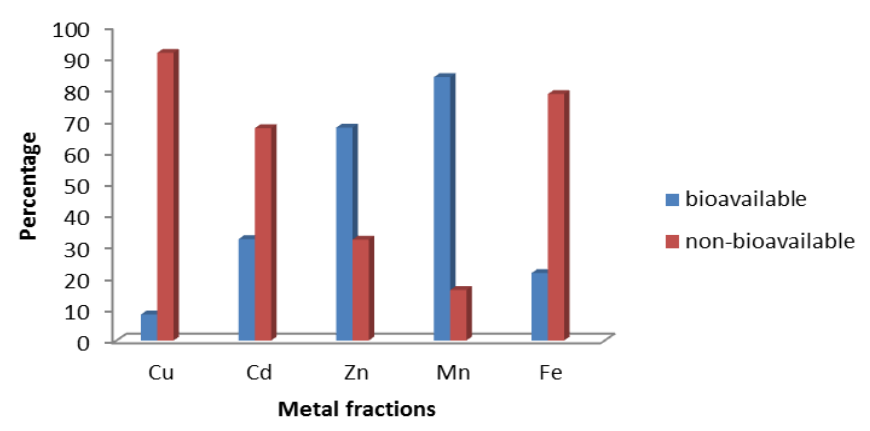

Figure 1c: Bioavailability level of metals in Agba dam sediment

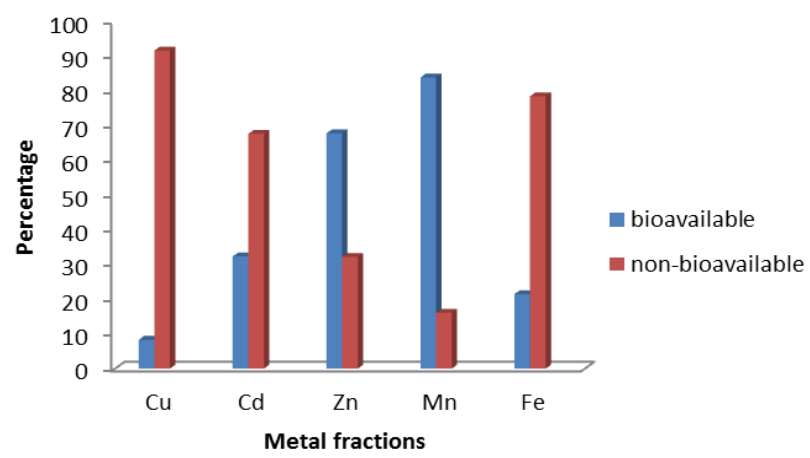

Figure 1d: Bioavailability level of metals in Omu-Aran dam sediment

sediments studies (Praveena et al., 2008). The $I_{g e o}$ is expressed as:

$$
I_{g e o}=\log _{2}\left(\frac{\mathrm{Cn}}{1.5 \mathrm{Bn}}\right)
$$

Where, $C_{n}$ is measured concentration of heavy metal in the sediment, $B_{n}$ is geochemical background value in average shale (Turekian and Wedepohl, 1961) of element $n, 1.5$ is the background matrix correction factor due to lithogenic effects.

Geoaccumalation indices are classified into 6 distinct classes for the assessment of sediment pollution load. These are: < 0 (class 0) Uncontaminated, 1 (class 1) Uncontaminated to moderately contaminated, 2 (class 2) Moderately contaminated, 3(class 3) Moderately to highly contaminated, 4 (class 4) Highly contaminated, 5 (class 5) Highly to very highly contaminated, 6 (class 6) Very highly contaminated (Seshan et al., 2010). 
The geo-accumulation index (Table 8 ) of the dams sediments is uncontaminated $(<0)$ for all the metals analyzed except for $\mathrm{Cd}$ being uncontaminated to moderately contaminated in Oloru and Omu-Aran dams. The $\mathrm{Cd}$ violation is in agreement with the observed concentration in dams' water.

\section{Conclusion}

The analysis of the water quality parameters of Agba, Igbaja, Oloru and Omu-Aran dams show that $\mathrm{pH}, \mathrm{DO}, \mathrm{BOD}$, total hardness, alkalinity, chloride, phosphate, nitrate and sulphate values are well within the permissible limits for drinking water set by World Health Organization. The heavy metals analyzed in the water sample shows that the dams are highly contaminated with $\mathrm{Cd}, \mathrm{Mn}$ and Fe because the concentration levels obtained in this study showed that these metals are higher than WHO standard limits for drinking water.

Although, most of the heavy metals analyzed in the sediments of the dams show that a larger percentage of the metals occurs in the nonbioavailable fractions, it is also necessary to know that the fractions present in the bioavailable fractions could also be a source of problem to the aquatic environment because this could be leached to the water body when the right $\mathrm{pH}$ of the environment is attained thereby causing health related problems to the consumers. The $I_{g e o}$ of the sediment shows that the sediment is not highly contaminated by human activities. It is therefore recommended that government should establish an effective monitoring program that would ensure that these water quality parameters are monitored periodically.

\section{References}

Abdel-Baky, T.E., Hagras, A.E., Hassan, S.H. and Zyadah, M.A. (1998). Environmental impact assessment of pollution in lake Manzala, IDistribution of some heavy metals in water and sediments. Journal of the Egyptian German Society of Zoology 26(8):25-38.
Abdus-Salam, N., Bale, R.B., Taorid, R. and Adeniyi, O.O. (2013). Studies of water and sediment quality of Owalla dam, Osun state, Nigeria. Fountain Journal of Natural and Applied Sciences 2(2): 22-31.

Adakole, J.A., Abulode, D.S. and Balarabe, M.L. (2008). Assessment of water quality of a man- made lake in Zaria, Nigeria. Proceedings of Taal 2007: The $12^{\text {th }}$ World Lake Conference: 1373-1382.

Adefemi, O.S., Olaofe, O. and Asaolu, S.S. (2007). Assessment of the Physicochemical Status of Water Samples from Major Dams in Ekiti State, Nigeria. Pakistan Journal of Nutrition, 6 (6): 657-659.

Adekola, F. A., Abdus-Salam, N.; Bale, R. B. and Oladeji I. O. (2010) Sequential extraction of trace metals and particle size distribution studies of Kainji Lake sediment, Nigeria. Chemical Speciation and Bioavailability 22(1): 43- 49.

Adekola, F.A., Salami, N. and Lawal, S.O. (2003) Trace elements in surface water and sediments of Oyun River, Kwara State, Nigeria. Nigeria Journal of Pure and Applied Sciences, 18: 1418-1422.

Ademoroti, C.M.A. (1996a). Environmental Chemistry and Toxicology, Foludex Press Ltd Ibadan, Nigeria, pp. 58-188.

Ademoroti, C.M.A. (1996b). Standard methods for water and effluents analysis, Foludex Press Ltd; Ibadan, Nigeria, pp. 22 - 87.

Adeyeye, E.J. and Abulude, F. O. (2004). Analytical assessment of surface and ground water resources in Ile-Ife, Nigeria. Journal of Chemical Society of Nigeria, 29: 93-103.

Aiyesanmi, A.F. (2006). Baseline Concentration of Heavy Metals in Water Samples from Rivers Within Okitipupa South- east Belt of the Nigerian Bitumen Field. Journal of Chemical Society of Nigeria, 31, (1-2): 30-37.

Asaolu, S.S., Ipinmoroti, K.O.; Adeyinowo, C.E. and Olaofe, O. (1997). Interrelationship of 
heavy metals concentration in water, sediment as fish samples from Ondo State coastal Area, Nigeria. Africa Journal of Science 1: 55-61.

Asia, I. O. and Akporkhor, E.E. (2007) Characterization and Physiochemical treatment of waste water from rubber processing factory. International Journal of Physical Sciences, 2(3): 061-067.

Agency for Toxic Substances and Disease Registry (ATSDR) (1994). Toxicological Profile for Zinc. US Department of Health and Human Service, Public Health Service 205: 88-608.

Banker, A.B., Poogitha, S., Thirumala, S., Manjappa, E.T. and Puttaia (2010). Physicochemical analysis of Kathralu pond water near Chitradurga, Karnataka. Journal of Aquatic Biology, 25(2): 70-74

Bothkin, B.D. and Edward, K. (1997) Water Pollution and Treatment. Environmental Sciences, $2^{\text {nd }}$ edn, 424-425

Daniel, V.N. and Egila, J.N. (2011) Trace metals accumulation in freshwater and sediment insects of Liberty Dam, Plateau State, Nigeria. International Journal of Basic and Applied Sciences, 11(66):128.

Eaton, A.D. (2005). Standard Methods for the Examination of Water Wastewater. $21^{\text {st }}$ Edn. American Public Health Association, Washington, 21: 343-453.

Eddy, N.O., Odoemelam, S.A. and Mbaba, A. (2006). Elemental composition of soil in some dumpsites. Journal of Environmental, Agricultural and Food Chemicals, 5(3): 13491363.

Ehiagbonare, J.E and Ogunrinde Y.O. (2010) Physicochemical analysis of fish pond water in Okada and its environs, Nigeria. African Journal of Biotechnology, 9(36): 59225928.

Food and Agricultural Organization (FAO) (1997). Chemical Analysis Manual for Food and Water, FAO Rome 1: 20-26.
Fatoki, O.S., Lujiza, N. and Ogunfowokan, A.O. (2002) Trace metal pollution in Umtala River. Water (South Africa) 28:183-190.

Fernandez, L.G. and Olalla, H.Y (2000). Toxicity and bioaccumulation of lead and cadmium in marine protozoan communities. Ecotoxicology and Environmental Safety 47: 266-276.

Gomez-Ariza, J.L., Giraldez, I., Sanchez, R.D. and Moralesm, E. (2000). Metal sequential extraction procedure optimized for heavy metal polluted and iron-oxide rich sediments. Analytical Chimica Acta 414: 151164.

Gupta S., Bhatnagar, M. and Jain, R. (2003) Physicochemical Characteristics and Analysis of $\mathrm{Fe}$ and $\mathrm{Zn}$ in tube well water and sewage water of Bikanar City. Asian Journal of Chemistry, 15:727-734.

Helmke, P.A., Koons, R.D, Schomberg, P.J. and Iskandar, I.K (1977). Determination of trace element contamination of sediments. Environmental Science Technology 11:984989

Himrangshu, S.M., Amrita, D., Ashis, K.N. (2012) Study of some physicochemical water quality parameters of Karola River, West Bengal-an attempt to estimate pollution status. International Journal of Environmental Protection, 2 (8): 16-22.

Howari, F.M. and Banat, K.M. (2001) Assessment of $\mathrm{Fe}, \mathrm{Zn}, \mathrm{Cd} \mathrm{Hg}$ and $\mathrm{Pb}$ in Jordan and Yormouk river sediments in relation to their physicochemical properties and sequential extraction characterization. Water, Air and Soil pollution, 132: 43-59.

Ibe, K.M (1988). Environmental contamination and other anthropogenic impacts on Otamiri and Nwaore Rivers, Owerri, Nigeria. Environmental Pollution, 4: 27

Ireland Environmental Protection Agency (IEPA) (2001). Parameters of Water Quality: Interpretation and Standards, Environmental Protection Agency, Johnstown, p. 133. 
Iqbal, F., Ali, M., Salam, A., Khan, B.A. Ahmed, S., Qamar, M. and Kashif, U. (2004). Seasonal variations of physicochemical characteristics of River Soan water at Dhoak pathan Bridge (Chakwal), Pakistan. International Journal of Agriculture and Biology 6(1): 89-92.

Iwegbue, C.M.A., Nwajei, G.E. and Arimoro, F.O. (2007). Assessment of contamination by heavy metals in sediments of Asa River, Niger Detal, Nigeria. Research Journal of Environmental Sciences, 1:220-228

Linnik, P.M. and Zubenko, I.B. (2000). Role of bottom sediments in the secondary pollution of aquatic environments by heavy metal compounds, Lakes and Reservoir. Research and Management 5: 11- 21

Manahan, S.E. (1999). Environmental Chemistry, Seventh edition, Lewis publishers, New York, London, Washington, p. 783.

Mason, C.F. (2002). Biology of Freshwater Pollution, $4^{\text {th }}$ ed. Essex University, England, p. 387.

Muhammed, M., Samira, S., Faryal, A. and Farruk, J. (2013) Assessment of drinking water quality and its impact on residents health in Behawal pur city, International Journal of Humanities and Social Science, 3(15): 114128.

Muller, G. (1979) Heavy metals in the sediment of the Rhine - Changes seity. Umschau in wissenschaft und technic 79: 778-783

Mustapha, M.K and Omotosho, J.S. (2005) An assessment of the physicochemical properties of Moro Lake, Kwara State, Nigeria. African Journal of Applied Zoology and Environmental Biology, 7:73-77.

Nada, S., Henri-Charles, D. and Tayssir, H. (2011) Sequential extraction and particle size analysis of heavy metals in sediment dredged the Deule canal, France. The open Environmental Engineering Journal, 4: 11-17

Nagendrappa, G., Kumar, M.M.S.Y., Abdulgalil, M.S. and Satish, M.A. (2007) A simple spectrophotometric determination of phosphate in Sugarcane Juices, Water and
Detergent Samples. E-Journal of Chemistry, 4(4): 467-473

Nigeria Industrial Standards (NIS) (2007). Standards Organization of Nigeria NIS 554, p. 30.

Ogoyi, D.O., Mwita, C.J., Nguu, E.K. and Shiundu, P.M. (2011). Determination of heavy metal content in water, sediment and microalgae from Lake Victoria, East Africa. The Open Environmental Engineering Journal, 4: 156161

Olajire, A.A. and Imeokparia, F.E. (2000). Asurvey of the water quality of the Osun River; metal monitoring and geochemistry. Bulletin of Chemical Society of Ethiopia, 14(1):91-108.

Patil, P.N., Sawant, D.V. and Deshmukh, R.N. (2012). Physico-chemical parameters for testing of water - A review, International Journal of Environmental Sciences 3(3): 1194-1198

Praveena, S.M., Ahmed, A., Radojevic, M., Abdullah, M.H. and Ris, A.Z., (2008). Heavy metals in mangrove surface sediments of Mengkabong Lagoon, Sabah: Multivariate and geoaccumulation index approaches. International Journal of Environmental Research, 2(2): 139-148.

Quadri, N.N., Seema, H., Asif, I. and Mohd, S. (2010). A study on physicochemical parameters of river Bindusara, Beed, Marashtra. Journal of Aquatic Biology, 25(2):100-103

Rao, P. V. (2005) Textbook of Environmental Engineering. Eastern Economy Ed., PrenticeHall of India Private Limited, New Delhi, Chapter 3, p. 280.

Rizwan, R.F., Jain, M.K. and Singh, G. (2009) Pre and Post Monsoon variation of heavy metals concentration in Ground water of AngulTalcher region of Orissa, India, Nature and Science 7(6): 52-56

Samir, M.S. and Ibrahim, M.S. (2008) Assessment of heavy metals pollution in water and sediments and their effect on Oreochromis niloticus in the northern delta lakes, Egypt. International symposium on Tilapia in Aquaculture, p. 475. 
Sangpal, R.R., Kulkarni, U.D. and Nandurkar, Y.M. (2011) An assessment of the Physicochemical Properties to study the pollution potential of Ujjani reservoir, Solapur District India. ARPN Journal of Agricultural and Biologiocal Science 6(3): 34-38.

South African Water Quality Guidelines (SAWQG) (1996). Agricultural Water Use: Aquaculture, 2nd Edition, Vol. 6, Department of Water Affairs and Forestry of South Africa, Pretoria, p. 185.

Sayyed, H., Vidya, P. and Mazahar, F. (2012) Physicochemical analysis of Limboti dam water, district Nanded, Maharashtra. Journal of Advanced Scientific Research 3(1): 55-57.

Seshan, B.R.R., Natesan, U. and Deepthi, K. (2010) Geochemical and statistical approach for evaluation of heavy metal pollution in core sediments in southeast coast of India. International Journal of Environmental Science and Technology, 7(2): 291306. Turekian, K. K and Wedepohl, K. H., (1961). Distribution of the elements in some major units of the Earth's crust. Bulletin of Geological Society of America, 72 (2): 175192

United States Environmental Protection Agency (USEPA) (2002). List of drinking water contaminations and maximum contamination levels. EPA 816-F 02-013. Available at: http://www.epa.gov/safewater/mcl.html.

World Health Organization (WHO) (1993). Guidelines for drinking water quality. $2^{\text {nd }}$ edition World Health Organisation, Geneva, Switzerland 1: 1188

World Health Organization (WHO) (2006). Guidelines for drinking water quality, Geneva, Netherlands 1: 491-493. 